\title{
THE EFFECT OF MANGROVES AMENDMENTS TO SOIL ON ROOT ROT AND ROOT KNOT OF POTATO (SOLANUM TUBEROSUM L.).
}

\author{
Marium Tariq, Shahnaz Dawar, Fatima Sultana Mehdi, Muhammad Javed Zaki
}

\author{
Department of Botany, University of Karachi, Karachi - 75270, Pakistan \\ e-mail: shahnaz_dawar@yahoo.com
}

Received: 4.01.2008

\section{S u m m a r y}

Leaves, stem and pneumatophore of Avicennia marina and leaves and stem of Rhizophora mucronata were used as the organic amendments at $0.1,1$ and $5 \%$ concentrations in the control of root rot fungi like (Fusarium spp., Rhizoctonia solani and Macrophomina phasoelina) and root knot nematode Meloidogyne javanica on potato. In pot experiments, germination of seeds, shoot length, shoot weight, root length, root weight and number of knots were significantly increased when plant parts like leaves, stem and pneumatophore of $A$. marina and $R$. mucronata were used at 1 and $5 \%$ concentrations. There was a complete suppression in infection of $R$. solani and M. phaseolina when A. marina and $R$. mucronata were used at $5 \%$ concentration on potato. Maximum inhibition of knots of $M$. javanica was observed when powder made from mangrove plant parts was used at 1 and $5 \%$ concentrations. Powder from all plant parts, like leaves, stem and pneumatophore, was effective in suppression of root infecting fungi and root knot nematode.

Key words: Mangroves, control, root rot fungi, root knot nematode, potato

\section{INTRODUCTION}

Amendments provide energy and nutrients to soil, drastically changing the environment for the growth and survival of crops and micro-organisms (D r i n k w a t e r et al. 1995). Organic soil amendments are commonly used in the agricultural system to recycle nutrients and energy as well as to improve soil conditions for plant growth (Hadar et al. 1992; Muchovej and P a c ov s ky, 1997). Some organic amendments suppress soil-borne plant pathogens and several also control plant-parasitic nematodes (R o drigue z-K a b a n a, 1986; A 1 i et al. 2001). In general, soil amendment with toxic plants suppresses plant pathogens directly by releasing toxic substances like phenols, and indirectly enhancing soil micro-organisms that inhibit phytopatho- gens, and also plant-parasitic nematodes (Ali et al. 2001; S h a u k t et al. 2001).

The soil borne root-infecting fungus, Macrophomina phaseolina, is reported to produce charcoal rot of over 500 species of plants (S i n c l a i r, 1982). Rhizoctonia solani exists as active mycelium in the soil, attacks over 2000 species of plants (P a r m e te r, 1970), and Fusarium species (B o oth , 1971) are known to infect a wide range of host plants in different parts of the world. Soil borne root infecting fungi cause seed decay, root rot and stem rot of crop plants.

Root-knot nematodes Meloidogyne spp. are world wide in distribution and are known to attack a wide variety of crops (G o o d e y et al. 1965). Till now 70 species of Meloidogyne have been identified ( $\mathrm{L}$ u c et al. 1988). Only 4 species like $M$. incognita (Kofoid \& White) Chitwood, M. javanica (Treub) Chitwood, M. arenaria (Neal) Chitwood and M. hapla (Chitwood), are of major economic importance. The various species of Meloidogyne induce major morphological and physiological changes within roots. In nearly every crop yields and quality are reduced (S a s s e r, 1980). About 100 plants have been found to be infested with root-knot nematodes from different cultivated zones of Pakistan (Maqboo 1, 1988; Zaki, 2000). Damage caused by root-knot nematode is much higher in tropical and sub tropical countries (T a y 1 or and S a s s e r, 1978).

Pakistan has a coastline of about $1,000 \mathrm{~km}$. The Indus River Delta extends over $250 \mathrm{~km}$ from Sir Creek at the Indian Border and Karachi in the west with about 250,000 ha of mangroves ( $\mathrm{K} \mathrm{h}$ a n, 1966; M i r z a et al. 1983). The predominant species of mangrove is Avicennia marina, whereas Rhizophora mucronata comprises less than $5 \%$ area (S a i f u $11 \mathrm{a} \mathrm{h}, 1982)$. The mangrove plant parts are of various uses. Bark is used for tanning and dye. Leaves are the source of a black or chestnut dye (B u rki11, 1966). It is reported that mangrove is a folk remedy for angina, diabetes, diarrhea dysentery, 
hematuria and haemorrhage (D u k e and Wa i n, 1981). The aim of the present study was to determine the suppression of root rot and root knot nematode on potato (Solanum tuberosum L.) by dried powder of plant parts of A. marina and $R$. mucronata.

\section{MATERIALS AND METHODS}

Root rot fungi: Mangrove plant parts like leaves, stem and pneumatophore of Avicennia marina (Forsk.) Vierh and leaves and stem of Rhizophora mucronata Lamk were collected from Sonmiyani. The plant parts were washed, air dried and powdered in an electric grinder. Unsterilized sandy loam soil (sand, silt, clay; 70,19 and $11 \%$ respectively) of $\mathrm{pH} 7.5-8.1$ with moisture holding capacity (MHC) of $40 \%$ (Keen and Raczkowski, 1922), total nitrogen 0.077-0.099\% (Mackenzie and Wallace, 1954), total organic matter 4.17-4.59\% obtained from the experimental plots of the Department of Botany, University of Karachi, was mixed with powdered leaves, stem and pneumatophore of $A$. marina and leaves and stem of $R$. mucronata at concentrations of $0.1,1$ and $5 \%$. The soil had natural infestation of 4-6 sclerotia/g soil of Macrophomina phaseolina as found by wet sieving dilution technique (Sheikh and Ghaffar, 1975), 3-5\% colonization of Rhizoctonia solani on sorghum seeds used as baits (Wilh e $1 \mathrm{~m}, 1955)$ and $8 \times 10^{6} \mathrm{cfu} / \mathrm{g}$ soil of Fusarium sp., as assessed by soil dilution technique ( $\mathrm{N}$ a s $\mathrm{h}$ and S n y d e r, 1962).

The amended soil was placed in $8 \mathrm{~cm}$ diam. plastic pots@1 kg/clay pot and watered daily to facilitate the decomposition of the plant material. Ten days after amendment, 2 potato (Solanum tuberosum L.) seed tubers were sown in each pot. Treatments were replicated three times and the pots were kept in a randomized

Table 1

Effect of mangroves amendments to soil infected with pathogenic fungi on growth parameters of potato.

\begin{tabular}{|c|c|c|c|c|c|}
\hline \multicolumn{6}{|c|}{ Avicennia marina } \\
\hline Treatments & $\begin{array}{c}\text { Germination } \\
\%\end{array}$ & $\begin{array}{l}\text { Shoot length } \\
\text { (cm) }\end{array}$ & $\begin{array}{c}\text { Shoot weight } \\
\text { (g) }\end{array}$ & $\begin{array}{l}\text { Root length } \\
\text { (cm) }\end{array}$ & Root weight (g) \\
\hline Control & 50.00 & 13.83 & 2.98 & 18.16 & 0.63 \\
\hline $0.1 \%$ leaves & $66.66(33.32)$ & $14.28(3.25)$ & $2.90(2.68)$ & $14.56(19.82)$ & $0.70(11.11)$ \\
\hline $1 \%$ leaves & $83.33(66.66)$ & $16.00(15.69)$ & $3.86(29.53)$ & $18.25(0.49)$ & $0.89(41.26)$ \\
\hline $5 \%$ leaves & $100.00(100.0)$ & $17.41(25.88)$ & $3.99(33.89)$ & $18.63(2.58)$ & $0.9(42.85)$ \\
\hline $0.1 \%$ stem & $66.66(33.32)$ & $21.00(51.95)$ & $5.09(70.80)$ & $18.30(0.77)$ & $0.65(3.17)$ \\
\hline $1 \%$ stem & $83.33(66.66)$ & $21.00(51.95)$ & $5.11(71.47)$ & $22.43(23.51)$ & $0.99(57.14)$ \\
\hline $5 \%$ stem & $100.00(100.0)$ & $22.25(60.88)$ & $5.51(84.89)$ & $22.83(25.71)$ & $1.01(60.3)$ \\
\hline $0.1 \%$ pneumatophore & $50.00(0.00)$ & $14.84(7.32)$ & $2.99(0.33)$ & $18.60(2.42)$ & $0.64(1.58)$ \\
\hline $1 \%$ pneumatophore & $66.66(33.32)$ & $19.46(40.70)$ & $3.90(30.87)$ & $18.91(4.12)$ & $0.65(3.17)$ \\
\hline $5 \%$ pneumatophore & $83.33(66.66)$ & $23.66(71.07)$ & $4.14(38.92)$ & $19.06(4.95)$ & $0.74(17.46)$ \\
\hline LSD0.05 $=$ & 32.59 & 10.50 & 3.22 & 11.97 & 0.90 \\
\hline \multicolumn{6}{|c|}{ Rhizophora mucronata } \\
\hline Control & 66.66 & 9.81 & 1.94 & 10.6 & 0.34 \\
\hline $0.1 \%$ leaves & $66.66(0.00)$ & $10.18(3.77)$ & $1.81(6.70)$ & $11.05(4.24)$ & $0.37(8.82)$ \\
\hline $1 \%$ leaves & $100(50.01)$ & $11.41(16.30)$ & $2.63(35.56)$ & $11.24(6.03)$ & $0.43(26.47)$ \\
\hline $5 \%$ leaves & $100(50.01)$ & $12.38(26.19)$ & $3.35(72.68)$ & $12.72(20.00)$ & $0.53(55.88)$ \\
\hline $0.1 \%$ stem & $66.66(0.00)$ & $10.26(4.58)$ & $2.80(44.32)$ & $10.62(0.18)$ & $0.33(2.94)$ \\
\hline $1 \%$ stem & $83.33(25.00)$ & $12.21(24.46)$ & $2.83(45.87)$ & $10.95(3.30)$ & $0.38(11.76)$ \\
\hline $5 \%$ stem & $100(50.01)$ & $13.48(37.41)$ & $3.62(86.59)$ & $11.69(10.28)$ & $0.49(44.11)$ \\
\hline LSD0.05= & 36.31 & 1.08 & 1.04 & 1.80 & 0.15 \\
\hline
\end{tabular}

Parenthesis shows increase \% as compared to control. 
fashion on the screen house bench of the Department of Botany, University of Karachi, where soil was kept at $50 \%$ Water Holding Capacity (Ke e n and R a c zk o w s k i, 1922).

Plants were uprooted after 60 days of emergence and growth parameters in terms of plant height and fresh weight of shoot were recorded. To determine the incidence of fungi, one $\mathrm{cm}$ long root pieces, after washing in running tap water, were surface sterilized with $1 \% \mathrm{Ca}(\mathrm{OCl})_{2}$ and transferred on PDA plates supplemented with penicillin at $200 \mathrm{mg} / \mathrm{l}$ and streptomycin at $200 \mathrm{mg} / 1$ at 5 pieces per plate. Petri dishes were incubated at room temperature and after one week, infection of roots by root infecting fungi ( $\mathrm{S}$ i d d i q u i et al. 1999) was recorded as follows:

Infection $\%=($ Number of plants infected by fungus/Total number of plants) X 100
Root knot nematode: The roots of brinjal (Solanum melongena) infested with root knot nematode M. javanica were collected from the experimental plot of Department of Botany, University of Karachi. The roots were washed under running tap water and cut into small pieces, then dipped in $100 \mathrm{ml}$ of $1 \% \mathrm{Ca}(\mathrm{OCl})_{2}$ in a bottle and the mouth was tightly closed, then shaken vigorously by hand for $5 \mathrm{~min}$ and the content was poured onto a 100 mesh sieve fitted over a 400 mesh sieve, the roots were washed under running tap water for $1 \mathrm{~min}$, the residues from the 400 mesh sieve were transferred into a $250 \mathrm{ml}$ beaker. Number of eggs and larvae/ml of suspension were determined with the help of a counting dish (H u s e y and B arker, 1973). The population of pathogens in soil and experimental design were same as described in root infecting fungi.

Table 2

Effect of mangroves amendments to soil on infection \% of Fusarium spp., Rhizoctonia solani and Macrophomina phaseolina on potato plant.

\begin{tabular}{|c|c|c|c|}
\hline \multicolumn{4}{|c|}{ Avicennia marina } \\
\hline Treatments & Fusarium spp. & Rhizoctonia solani & Macrophomina phaseolina \\
\hline Control & 100.00 & 96.66 & 100.00 \\
\hline $0.1 \%$ leaves & $83.33(16.67)$ & $70.00(27.58)$ & $90.00(10)$ \\
\hline $1 \%$ leaves & $43.33(56.67)$ & $36.66(62.07)$ & $46.66(53.34)$ \\
\hline $5 \%$ leaves & $13.33(86.67)$ & $6.66(93.10)$ & $16.66(83.34)$ \\
\hline $0.1 \%$ stem & $53.33(46.67)$ & $30.00(68.96)$ & $46.66(53.34)$ \\
\hline $1 \%$ stem & $26.66(73.34)$ & $20.00(79.30)$ & $23.33(76.67)$ \\
\hline $5 \%$ stem & $6.66(93.34)$ & $0.00(100)$ & $10.00(90.00)$ \\
\hline $0.1 \%$ pneumatophore & $43.33(56.67)$ & $53.33(44.82)$ & $56.66(43.34)$ \\
\hline $1 \%$ pneumatophore & $33.33(66.67)$ & $36.66(62.07)$ & $23.33(76.67)$ \\
\hline $5 \%$ pneumatophore & $6.66(93.34)$ & $3.33(96.55)$ & $10.00(90.00)$ \\
\hline LSD0.05 = & 30.52 & 26.86 & 21.44 \\
\hline \multicolumn{4}{|c|}{ Rhizophora mucronata } \\
\hline Control & 100.00 & 96.66 & 100.00 \\
\hline $0.1 \%$ leaves & $93.33(6.67)$ & $76.66(20.69)$ & $80.00(20.00)$ \\
\hline $1 \%$ leaves & $40.00(60.00)$ & $13.33(86.20)$ & $20.00(80.00)$ \\
\hline $5 \%$ leaves & $6.66(93.34)$ & $0.00(100.00)$ & $0.00(100.00)$ \\
\hline $0.1 \%$ stem & $96.66(3.34)$ & $66.66(31.03)$ & $86.66(13.34)$ \\
\hline $1 \%$ stem & $40.00(60.00)$ & $13.33(86.20)$ & $23.33(76.67)$ \\
\hline $5 \%$ stem & $3.33(96.67)$ & $0.00(100.00)$ & $6.66(93.34)$ \\
\hline LSD0.05= & 20.23 & 17.21 & 15.20 \\
\hline
\end{tabular}

Parenthesis shows reduction \% as compared to control. 
Fifteen days after potato emergence, the soil in each pot was inoculated with 2000 juveniles of $M$. javanica. The juveniles were less than one week old and were obtained from infected brinjal (Solanum melongena L.) roots. Soil without mangrove plant parts served as the control. There were three replicates of each treatment and pots were kept randomized in a screen house of the Department of Botany, University of Karachi. The experiment was terminated 65 days after nematode addition, and plant growth parameters in terms of shoot length, shoot weight, root length, root weight were recorded. Infection on roots by root knot nematodes was recorded.
Data were subjected to analysis of variance (ANOVA) followed by the least significant difference (LSD) test and Duncan's multiple range test according to $\mathrm{G}$ o $\mathrm{mez}$ and G o mez (1984).

\section{RESULTS}

Root rot fungi: In potato a maximum increase in germination of seeds was observed where A. marina leaves and stem powder was used at a $5 \%$ concentration $(100 \%)$ (Tab. 1). The growth parameters like shoot length, root length, shoot weight and root weight showed that the highest increase in length of shoot $(60.88 \%)$

Table 3

Effect of mangroves amendments to soil on root knot of potato.

\begin{tabular}{|c|c|c|c|c|c|c|}
\hline \multicolumn{7}{|c|}{ Avicennia marina } \\
\hline Treatments & $\begin{array}{c}\text { Germination } \\
\%\end{array}$ & $\begin{array}{l}\text { Shoot length } \\
\text { (cm) }\end{array}$ & $\begin{array}{c}\text { Shoot weight } \\
\text { (g) }\end{array}$ & $\begin{array}{l}\text { Root length } \\
(\mathrm{cm})\end{array}$ & $\begin{array}{c}\text { Root weight } \\
\text { (g) }\end{array}$ & $\begin{array}{c}\text { Number of } \\
\text { knots }\end{array}$ \\
\hline Control & 83.33 & 18.16 & 2.48 & 19.58 & 1.41 & 64 \\
\hline $0.1 \%$ leaves & $66.66(20.00)$ & $27.50(51.43)$ & $5.64(127.41)$ & $18.83(3.83)$ & $1.05(25.53)$ & $32(50.00)$ \\
\hline $1 \%$ leaves & $83.33(0.00)$ & $27.66(52.31)$ & $6.34(155.6)$ & $20.08(2.55)$ & $1.24(12.05)$ & $10(84.37)$ \\
\hline $5 \%$ leaves & $100.00(20.00)$ & $28.96(59.47)$ & $7.14(187.90)$ & $25.00(27.6)$ & $2.33(65.24)$ & $0.0(100.00)$ \\
\hline $0.1 \%$ stem & $83.33(0.00)$ & $22.66(24.77)$ & $5.51(122.17)$ & $24.00(22.57)$ & $2.99(112.0)$ & $10(84.37)$ \\
\hline $1 \%$ stem & $83.33(0.00)$ & $22.75(25.27)$ & $5.92(138.70)$ & $25.16(28.49)$ & $3.01(113.47)$ & $2.0(96.87)$ \\
\hline $5 \%$ stem & $100.00(20.00)$ & $23.66(30.28)$ & $6.17(148.79)$ & $25.66(31.05)$ & $3.35(137.58)$ & $1.0(98.43)$ \\
\hline $\begin{array}{l}0.1 \% \\
\text { pneumatophore }\end{array}$ & $50.00(39.99)$ & $18.85(3.79)$ & $3.58(44.35)$ & $19.88(1.53)$ & $1.63(15.60)$ & $20(68.75)$ \\
\hline $1 \%$ pneumatophore & $100.00(20.00)$ & $19.76(8.81)$ & $3.88(56.45)$ & 20.95 (6.99) & $3.05(116.3)$ & $2.0(96.87)$ \\
\hline $5 \%$ pneumatophore & $100.00(20.00)$ & $24.53(35.07)$ & $5.38(116.9)$ & $22.96(17.26)$ & $3.39(140.42)$ & $0.0(100.00)$ \\
\hline LSD0.05= & 35.78 & 21.24 & 4.74 & 16.76 & 1.88 & 10.98 \\
\hline \multicolumn{7}{|c|}{ Rhizophora mucronata } \\
\hline Control & 66.66 & 9.99 & 2.51 & 10.18 & 0.24 & 48 \\
\hline $0.1 \%$ leaves & $83.33(25.00)$ & $12.46(24.72)$ & $3.24(29.08)$ & $10.82(6.28)$ & $0.33(37.5)$ & $30(37.5)$ \\
\hline $1 \%$ leaves & $100(50.00)$ & $13.0(30.13)$ & $4.28(70.51)$ & $11.42(12.18)$ & $0.37(54.16)$ & $2.0(95.83)$ \\
\hline $5 \%$ leaves & $100(50.00)$ & $14.54(45.54)$ & $4.74(88.84)$ & $12.32(21.02)$ & $0.47(95.83)$ & $1.0(97.91)$ \\
\hline $0.1 \%$ stem & $83.33(25.00)$ & $10.48(4.90)$ & $3.05(21.51)$ & $10.74(5.50)$ & $0.26(8.33)$ & $24(50.00)$ \\
\hline $1 \%$ stem & $100(50.00)$ & $11.70(17.11)$ & $4.15(65.33)$ & $11.59(13.85)$ & $0.39(62.5)$ & $7.0(85.41)$ \\
\hline $5 \%$ stem & $100(50.00)$ & $13.76(37.73)$ & $4.35(73.30)$ & $11.76(15.52)$ & $0.42(75.00)$ & $0.0(100)$ \\
\hline LSD0.05= & 35.43 & 1.85 & 1.31 & 1.76 & 0.12 & 5.33 \\
\hline
\end{tabular}

Parenthesis shows reduction \% in number of knots and increase \% in growth parameters as compared to control. 
$(71.07 \%)$ and root $(25.71 \%)(4.95 \%)$ was observed at 1 and $5 \%$ concentrations of stem and pneumatophore powder of $A$. marina. A maximum increase in root $(60.3 \%)(17.46 \%)$ and shoot weight $(84.89 \%)(38.92 \%)$ was observed at 1 and $5 \%$ concentrations of stem and pneumatophore powder. There was an increase $(26.19 \%)$ $(37.41 \%)$ in shoot length and shoot weight $(72.68 \%)$ $(86.59 \%)$ of $R$. mucronata leaves and stem powder used at $5 \%$ concentration. There is a maximum increase in germination, shoot weight and root weight which is used at $5 \%$ concentration as compared to the control (Tab. 1). $A$. marina showed the longer shoot and root length as compared to $R$. mucronata plant parts.

Infection by root rot fungi was reduced when $A$. marina and $R$. mucronata plants powder was applied at $5 \%$ concentration. $A$. marina stem powder used at $5 \%$ concentration showed complete suppression (100\%) of $R$. solani. Similarly, the infection by M. phaseolina and $R$. solani was completely suppressed (100\%) when $R$. mucronata plant parts were used at 5\% concentration. Leaves powder of $R$. mucronata was the most effective in the control of root infecting fungi, whereas stem powder of $A$. marina was the most effective (Table 2).

Root knot nematode: Soil amendment with A. marina leaves, stem and pneumatophore at 1 and $5 \%$ concentrations reduced the root knot development on potato followed by $R$. mucronata as compared to the control (Tab. 3). Soil amendment at 1 and 5\% concentrations also increased the plant height, weight and root weight of $R$. mucronata. The plant showed maximum germination when A. marina (20.00\%) and R. mucronata $(50.00 \%)$ plant parts were used at 1 and $5 \%$ concentrations. Complete suppression of root knot (100\%) was observed when $A$. marina leaves and pneumatophore were used at $5 \%$ concentration, whereas $R$. mucronata stem powder showed complete suppression of root knot at $5 \%$ concentration. Of the different mangrove plant parts used, leaves showed better results on the growth of the plant, whereas the stem and pneumatophore of A. marina showed better results in suppression of the number of root knots (Tab. 3). R. mucronata leaves powder significantly increased the growth parameters while stem powder showed maximum inhibition of root knots (Tab. 3).

\section{DISCUSSION}

The addition of organic materials to soil infested with plant pathogens has been clearly demonstrated as a satisfactory control method, particularly against root knot nematodes (Ehteshamul-Haque et al. 1995). The present study describes the effect of soil amendment with different plant parts of $A$. marina and $R$. mucronata in the control of root infecting fungi and root knot nematodes on potato. There are reports where soil amendments with oil cakes like cotton cake and neem cake showed significant results in the control of root infecting fungi: $F$. solani, M. phaseolina and $R$. solani (E h t e s h a m u l- H a qu e et al. 1995). Similarly, the use of seaweeds Stoechospermum marginatum, neem cake and cotton cake (E h t e s h a m u l- H a q u e et al. 1998) showed promising results in the control of root infecting fungi on sunflower. Germination of potato seeds, shoot length, root length, shoot weight and root weight were increased where A. marina and $R$. mucronata plant parts were used at 1 and 5\% concentrations. A similar result was observed by D a w a r et al. (2007) on mung bean and chick pea with Eucalyptus sp. The present result showed that infection by Fusarium spp., $R$. solani and $M$. phaseolina was reduced on potato when mangrove plant parts were used at 5\% concentration. S i m i la rly, M e h d i et al. (2000) showed that $R$. mucronata used alone or in combination with Paecilomyces lilacinus significantly suppressed root infecting fungi. Complete suppression of $R$. solani was observed on potato when $A$. marina and $R$. mucronata were used at $5 \%$ concentration.

In the present study germination of potato tubers, plant weight, height, root length and shoot length increased when $A$. marina parts and $R$. mucronata plant parts were used at 1 and $5 \%$ concentrations. Tariq et al. (2007) observed that germination and plant growth parameters were significantly increased in mash bean and okra plants when leaves and stem powder of $R$. mucronata were used at 5\% concentration. The present result showed that $A$. marina and $R$. mucronata stem powder were more effective as compared to leaves and pneumatophore powder in suppression of root knot, whereas Mehdi et al. (2001) reported that $A$. marina and $R$. mucronata with or without Pseudomonas aeruginosa significantly reduced the root knot infection in tomato. Similarly, the application of $P$. lilacinus on brinjal and mung bean (Z a k i and M a q b o 1, 1992) on groundnut ( $\mathrm{P}$ a te $\mathrm{l}$ et al. 1995) significantly controlled plant parasitic nematodes.

\section{CONCLUSION}

Use of organic amendments is a very promising method in the control of diseases in Pakistan for potato and other valuable crops. However, further research is required in order to enhance the impact of such amendments on pathogens.

\section{Acknowledgement}

The authors would like to acknowledge HEC (Higher Education Commission) for providing financial support in order to complete this work. 


\section{REFERENCES}

Ali N. I., Siddiqui I. A., Zaki M. J., Shaukat S. S., 2001. Nematicidal potential of Lantana camara against Meloidogyne javanica in mung bean. Nematologica Mediterranea, 29: 99-102.

Bo oth C., 1971. The genus Fusarium. Common Wealth Mycological Institute, Kew Surrey, England.

Burkill J. H., 1966. A dictionary of economic products of the Malay Peninsula. Art Printing works, Kuala Lumpur. 2 vols.

Dawar S., Younus S. M., Tariq M., Zaki M. J., 2007. Use of Eucalyptus sp., in the control of root infecting fungi on mung bean and chick pea. Pak. J. Bot. 39: 975-979.

Drinkwater L. E., Letourneau D. K., Workneh F., Van Bruggen A. H. C., Shennan C., 1995. Fundamental differences between conventional and organic tomato agroecosystem in California. Ecol. Applic. 5: 1098-1112.

Duke J. A., Wain K. K., 1981. Medicinal plants of the world. Computer index with more than 85,000 entries. 3 vols.

Ehtashamul-Haque S., Abid M., Ghaffar A., 1995. Efficacy of Bradyrhizobium spp., and Paecilomyces lilacinus with oil cakes in the control of root rot of mung bean. Tropical Science, 35: 294-299.

Ehteshamul-Haque S., Zaki M. J., Validy A. A., Ghaffar A., 1998. Effects of organic amendments in the efficacy of Pseudomonas aeruginosa in the control of root rot disease of sunflower. Pak. J. Bot. 30: 45-50.

Gomez K. A., Gomez A. A., 1984. Statistical procedures for Agricultural Research $2^{\text {nd }} e d$. Willey, New York.

Goodey J. B., Franklin, M. T., Hooper D. J., 1965. Goodey's the nematode parasites of plant Cataloylhed under their hosts. Farnham Royal, Common wealth Agriculture Bureax. $3^{\text {rd }}$ edition.

Hader Y., Mandelbaum R., Gorodecki B., 1992. Biological control of soil borne plant pathogens by suppressive compost. In: Biological Control of Plant Diseases, (Tjamos E. C., Papavizas G. C., Cook R. J. ed.), Plenum Press, New York, NY, USA: 79-83.

Hussey R. S., Barker K. R., 1973. A comparison of methods of collecting inocula of Meloidogyne spp, including a new technique. P1. Dis. Report. 57: 1025-1028.

Keen B. A., Raczkowski H., 1922. The relation between clay contents and certain physical properties of soil. J.Agric. Sci. 11: 441-449.

Khan S. A., 1966. Working plan of the Coastal Zone Afforestation Division from 1963-64 to 1982-83. Government of West Pakistan. Agriculture Dept., Lahore.

Luc M., Magneetic A. R., Fortuner R., 1988. A reappraisal of Tylenchina (Nematol) 9. The family Heteroidae Filip've and Schuurmans Stekhovem, 1941. Revue Nematol. 11: 159-176.

Mackanzie H. A., Wallace H. S., 1954. The kjeldahl determination of nitrogen. A critical study of digestion conditions, temperature, catalyst and oxidizing agents. Aust. J. Chem. 7: 55-70.
Maqbool M. A., 1988. An overview of nematode problem and research in Pakistan. In Advances in Plant Nematology US-Pak Int. workshop on Plant Nematology, (1986). NNRC, University of Karachi, Karachi Pakistan.

Mehdi F. S., Siddiqui I. A., Ali N. I., Afzal M., 2000. Rhizosphere mycoflora of Black Mangrove Seedling at Karachi Coast. Pak. J. Biol Sci. 3: 1352-1353.

Mehdi F. S., Siddiqui I. A., Zia T., Ali N. I., 2001. Use of mangrove for the control of Meloidogyne javanica in tomato. Nematol. Medit, 29: 127-129.

Mirza M. I., Hassan M. Z., A khtar S., Ali J., 1983. Identification and urea estimation of mangrove vegetation in Indus Delta using Landsat data. Pakistan Space and Upper Atmosphere Research Commission.

Muchovej R. M. C., Pacovsky R. S., 1997. Future directions of by-products and wastes in agriculture. In: Agricultural Uses of By-Products and Wastes. (Rechcigl J. E., MacKinnon H.c., ed.), ACS Symposium Series, American Chemical Society Washington, DC, USA: 1-19.

Nash S. M., Snyder W. C., 1962. Quantitative estimations by plate counts of propagules of the bean root rot, Fusarium in field soils, Phytopath. 52:567-572.

Parmeter J. R. 1970. Rhizoctonia solani biology and pathology. Univ. of California Press, Berkeley Los Angeles and London. pp. 255.

Patel D. J., Vyas R. V., Patel B. A., Patel R. S., 1995. Bioefficacy of Paecilomyces lilacinus in controlling Meloidogyne javanica (pathotype-2) on ground nut Nematological Abstract, 66: 389.

Rodriguez-Kabana R., 1986. Organic and inorganic amendment of soil as nematode suppressent. J. Nematol. 18: 129-135.

Saifullah S. M., 1982. Mangrove ecosystem of Pakistan, In: The third Research on Mangroves in Middle East, Japan Cooperative Centre for the Middle East. Publ. No. 137. Tokyo, Japan: 69-80.

S a s ser J. N., 1980. Root knot nematode. A global menace to crop production. Plant Disease. 104: 36-41.

Shaukat S. S., Siddiqui I. A., Ali N. I., Zaki M. J., 2001. Biological and chemical control of root infecting fungi and their effect on growth of mung bean. Pak. J. Biol. Sci. 4: 1240-1242.

Sheikh A. H., Ghaffar A., 1975. Population study of Sclerotia of Macrophomina phaseolina in cotton field. J. Bot. 7: 13-17.

Siddiqui I. A., Shaukat S. S., Ehteshamul-Haque S., Khan S. A. J., 1999. Effect of systemic fungicides on the efficacy of Pseudomonas aeruginosa (Schroeter) migula in the control of root-infecting fungi of wheat. Acta Agrobot. 2: 39-46.

Sinclair J. B., 1982. Compendium of soybean diseases, $2^{\text {nd }}$ ed. American Phytopathological society.

Tariq M., Dawar S., Mehdi F. S., Zaki M. J., 2007. Use of Rhizophora mucronata in the control of Meloidogyne javanica root knot nematode on okra and mash bean. Pak. J. Bot. 39: 265-270. 
Taylor A. I., Sasser J. N., 1978. Biology, identification and control of root knot nematodes (Meloidogyne species). North Carolina State University, Raleigh, Graphics, USA.

Wilhem S., 1955. Longevity of the Verticillium with fungus in the laboratory and field. Phytopathol. 45: 180-181.

Zaki M. J., Maqbool M. A., 1992. Effects of Pasteuria penetrans and Paecilomyces lilacinus on the control of root knot nematodes on brinjal and mung bean. Pak. J. Nematol. 10: 75-79.

Zaki M. J., 2000. Biomanagement of root-knot nematodes problem of vegetables. DFID, UK Research Project Report. Department of Botany. University of Karachi, Karachi -75270 .

\section{Wpływ dodatków do gleby z roślin namorzynowych na zgniliznę korzeni i narośla na korzeniach ziemniaka (Solanum tuberosum L.).}

\section{Streszczenie}

Liście, łodygi i pneumatofory Avicennia marina oraz liście i łodygi Rhizophora mucronata zastosowano jako organiczne dodatki do gleby w stężeniu 0,1 , 1 i 5\% do zwalczania grzybów powodujących zgniliznę korzeni, takich jak Fusarium spp., Rhizoctonia solani i Macrophomina phasoelina, oraz nicieni Meloidogyne javanica powodujących narośla na korzeniach ziemniaka. W doświadczeniach wazonowych kiełkowanie nasion, masa pędu, długość korzenia, masa korzenia znacznie zwiększyły się, a liczba narośli zmniejszyła się, kiedy części roślin $A$. marina i $R$. mucronata, takie jak liście, łodygi i pneumatofory, stosowano w stężeniu 1 i $5 \%$. Nastapiło zupełne zablokowanie zakażenia przez $R$. solani i $M$. phaseolina, kiedy części roślin A. marina i $R$. mucronata stosowano w stężeniu $5 \%$ w uprawach ziemniaka. Maksymalne zahamowanie narośli wywoływanych przez $M$. javanica obserwowano, kiedy proszek zrobiony z części roślin namorzynowych stosowano w stężeniu 1 i 5\%. Proszek ze wszystkich części roślin, takich jak liście, łodygi i pneumatofory, był skuteczny w blokowaniu działania grzybów porażających korzenie i nicieni Meloidogyne javanica. 
